\title{
Exploring flow rate selection in HIPEC procedures
}

\section{Explorando parâmetros de fluxo em procedimentos de HIPEC}

Thales Paulo Batista, tCbC-Pezi, ; Levon Badiglan Filho'; Cristiano Souza leão².

A B S T R A C T

Cytoreductive surgery (CRS) plus hyperthermic intraperitoneal chemotherapy (HIPEC) has emerged as a main comprehensive treatment of peritoneal malignancies. However, current data on the literature are very heterogeneous in terms of its technical particularities, which require some efforts to standardization of practices. In these setting, we present some early data from a pioneering clinical trial in Brazil (ClinicalTrials. gov Identifier: NCT02249013) to explore the dynamic relationships between flow rates and temperature parameters in the first cases of our study, which may help in selecting better technical parameters during HIPEC procedures.

Keywords: Injections, Intraperitoneal. Hyperthermia, Induced. Drug Therapy. Peritoneal Neoplasms.

\section{INTRODUCTION}

C ytoreductive surgery (CRS) plus hypertermic intraperitoneal chemotherapy (HIPEC) has emerged as a main comprehensive treatment of peritoneal malignancies. The rationale of combining heat with intraperitoneal chemotherapy is the synergistic effect of heat with the cytotoxic drugs. Heat has a direct cytotoxic effect, potentiates the action of certain antimitotic agents, as well as increasing their penetration into tumor tissue. Similarly, hyperthermia can also reduce the mechanisms of tumoral resistance to chemotherapy and induce an efficient anticancer immune response ${ }^{1}$. In summary, these arguments have highlighted HIPEC as a promising oncological approach.

Many HIPEC techniques have been described and the current data are heterogeneous in terms of technical procedures, which require some standardization of practices that might permit systematic comparisons. The technical particularities of HIPEC include instillation circuit, timing of parietal closure, length of perfusion, target temperatures, and choice and dosage of antimitotic agents. Herein, flow rate is an important variable in achieving and maintaining goal temperatures during HIPEC, whereas a minimal temperature threshold is also critical to improve chemotherapy effects and survival outcomes ${ }^{2,3}$. In this setting, we aimed to explore the dynamic relationship between flow rates and temperature parameters during HIPEC procedures to help selecting a target flow rate set up.

\section{TECHNICAL NOTE}

This note involves a cross-sectional analysis of early data from our ongoing clinical trial (ClinicalTrials.gov Identifier: NCT02249013) regarding HIPEC procedures - the very first Brazilian clinical trial on this matter. This study is testing a short-term protocol of cisplatin-based HIPEC for treatment of peritoneal carcinomatosis of ovarian origin. Details of the study design are available at https://clinicaltrials.gov/ct2/show/NCT02249013?ter$m=H I P E C+A N D+$ ovarian+cancer\&rank=4. Shortly, HIPEC was held immediately after cytorreduction according to the closed-abdomen technique. Our protocol involves the use of cisplatin $\left(25 \mathrm{mg} / \mathrm{L}\right.$ of perfusate $/ \mathrm{m}^{2}$, total limit of $240 \mathrm{mg}$ ) for 30 minutes with an intra-abdominal target temperature of $41-43^{\circ} \mathrm{C}$. Perfusate $\left(2 \mathrm{~L} / \mathrm{m}^{2}\right.$, ranging from $4 \mathrm{~L}$ to $6 \mathrm{~L}$ ) circulated using an extracorporeal circulation device named Performer HT (RanD, Medolla, Italy - Figure 1), and the goal temperature was set up to $44^{\circ} \mathrm{C}$. A flow rate of 300-500 ml/min was applied during the "patient filling phase" and increased to $700-1000 \mathrm{ml} / \mathrm{min}$ during

1 - A.C. Camargo Cancer Center, Department of Gynecology, São Paulo, São Paulo State, Brasil. 2 - Pernambucan Health Faculty and Professor Fernando Figueira Institute of Integral Medicine (FPS/IMIP), Department of Surgery, Recife, Pernambuco State, Brazil. 3 - Pernambuco Cancer Hospital (HCP), Department of Gynecology, Recife, Pernambuco State, Brazil. 
Table 1. Summary of relationship between flow rates and temperature parameters in HIPEC procedures.

\begin{tabular}{lcccccc}
\hline Parameters[1] & $600 \mathrm{ml} / \mathrm{min}$ & $700 \mathrm{ml} / \mathrm{min}$ & $800 \mathrm{ml} / \mathrm{min}$ & $900 \mathrm{ml} / \mathrm{min}$ & $1000 \mathrm{ml} / \mathrm{min}$ & $p$-value[2] \\
\hline $\begin{array}{l}\text { Inlet Temperature } \\
43.6(43.6-43.7)\end{array}$ & $43.3(43.2-43.4)$ & $42.8(42.8-42.9)$ & $42.8(42.7-42.8)$ & $41.8(41.7-41.8)$ & $<0.001$ \\
\hline $\begin{array}{l}\text { Outlet } \\
\text { Temperature }\end{array}$ & $40.6(40.5-40.7)$ & $41.2(41.1-41.3)$ & $41.0(40.9-41.0)$ & $40.6(40.5-40.6)$ & $40.7(40.6-40.7)$ & $<0.001$ \\
\hline $\begin{array}{l}\text { Mean } \\
\text { Temperature[3] }\end{array}$ & $42.1(42.1-42.2)$ & $42.2(42.2-42.3)$ & $41.9(41.9-41.9)$ & $41.7(41.6-41.7)$ & $41.2(41.1-41.2)$ & $<0.001$ \\
\hline $\begin{array}{l}\text { Temperature } \\
\text { Lost[4] }\end{array}$ & $3.1(2.9-3.2)$ & $2.1(2.0-2.3)$ & $1.8(1.8-2.0)$ & $2.2(2.2-2.3)$ & $1.1(1.0-1.2)$ & $<0.001$ \\
\hline
\end{tabular}

[1] Descriptive statistics summarized as median and IQR (interquartile range).

[2] According to Kruskal-Wallis test.

[3] Mean temperature: mean between inlet and outlet temperature probes.

[4] Temperature lost: difference between the inlet and outlet temperature probes.

the early "circulation phase". Thereafter, flow rate was adjusted between 600 to $1000 \mathrm{ml} / \mathrm{min}$ at intervals of $100 \mathrm{ml} / \mathrm{min}$, maintaining stable parameters into the peritoneal cavity just before the "drug circulation phase".

The device provided us with the main functional and patient parameters, and we recorded data from the "HIPEC phase" every minute. We permitted variations of $\pm 10 \%$ in the flow rate values and rounded them accordingly. Flow rates were related to temperature parameters. We summarize descriptive statistics as median and interquartile range. We performed the statistical analysis and graph construction applying conventional methods in the STATISTICA Data Analysis Software System, Version 8.0 (Statsoft, Inc., Tulsa, OK, USA).

Data from the first five cases enrolled into our trial were analyzed involving 148 time-points of information, since two records were excluded because a variation higher than $10 \%$ in the flow rate. The mean of inlet temperature and losses from solution to peritoneal cavity was lower at $1000 \mathrm{ml} / \mathrm{min}$. Conversely, a lower rate resulted in higher inlet temperatures and temperature losses. Differences between inlet and outlet temperature probes were about $3^{\circ} \mathrm{C}$ at a flow rate of $600 \mathrm{ml} / \mathrm{min}$, and $1^{\circ} \mathrm{C}$ at $1000 \mathrm{ml} / \mathrm{min}$. The temperature lost to peritoneal cavity remained virtually stable by about $2^{\circ} \mathrm{C}$ at flow rates of 700,800 and $900 \mathrm{ml} / \mathrm{min}$. Table 1 summarizes these temperature parameters in regards to flow rates. Data on difference between inlet and outlet temperature probes is also presented in Figure 2.

\section{DISCUSSION}

HIPEC is now a preferred treatment of many peritoneal surface malignancies ${ }^{1}$. Unfortunately, no single technique has so far demonstrated its superiority, and several variations in techniques have produced heterogeneous and incomparable results. In this scenario, further efforts are needed to standardize the technical particularities of HIPEC, whereas temperature parameters and their dynamic relationship with other variables are important points to be scrutinized ${ }^{2-5}$.

HIPEC involves the continuous heating and circulation of chemotherapy throughout the abdominal cavity in an attempt to enhance cytotoxicity ${ }^{4}$. Accordingly, flow rate is an important variable in achieving and maintaining goal temperatures during HIPEC, and a temperature threshold above $40^{\circ} \mathrm{C}$ is also critical to significantly enhance chemotherapy effects and improve survival outcomes ${ }^{2-4}$. By exploring the dynamic relationship between temperature parameters and flow rates in the first cases of our clinical trial, we noted that a higher flow rate may minimize the exchanging of heat from the system to the perfusate solution (i.e.: the mean inlet temperature was lower at $1000 \mathrm{ml} / \mathrm{min}$ ) and from the solution to the peritoneal cavity (i.e.: the mean of temperature losses was also lower at $1000 \mathrm{ml}$ min). Conversely, a lower rate resulted in higher inlet temperatures and temperature losses. These findings confirm that heat exchanges are mitigated by higher flow rates, and that the peritoneal cavity may absorb 


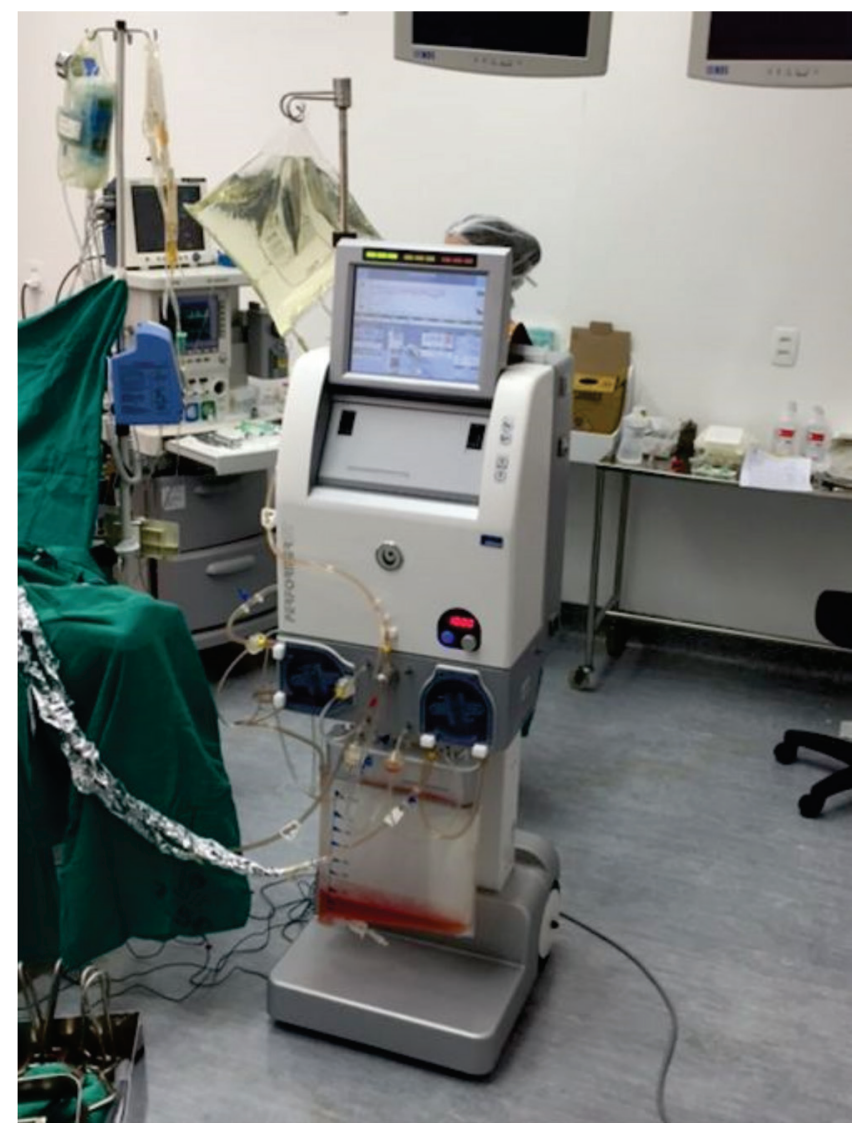

Figure 1. Performer HT device in use during HIPEC procedure.

more heat at lower flow rates. Herein, we found that the difference between inlet and outlet temperature probes were about $3^{\circ} \mathrm{C}$ at a flow rate of $600 \mathrm{ml} / \mathrm{min}$, and $1{ }^{\circ} \mathrm{C}$ at $1000 \mathrm{ml} / \mathrm{min}$. Interestingly, the temperature lost to peritoneal cavity remained virtually stable at about $2^{\circ} \mathrm{C}$ at a flow rate of 700,800 and $900 \mathrm{ml} / \mathrm{min}$.

Despite increased flow rates are important to achieve and maintain uniform temperature distribution throughout the abdominal cavity during HIPEC, the assumption of added benefit for increased flow rates requires further considerations ${ }^{2,4}$. For example, even though there is a greater rise in overall esophageal temperature during perfusion at higher rates of flow, the average esophageal temperatures were lower as the flow rate was increased according to Furman et al. ${ }^{2}$. In their study, the average esophageal temperature rise during perfusion was $1.0^{\circ} \mathrm{C}$ at $2500 \mathrm{ml} / \mathrm{min}$, a similar temperature gradient that we found at a flow rate of $1000 \mathrm{ml} / \mathrm{min}$. Thus, we could suppose stable differences between inlet and outlet temperature (i.e.: heat lost to the peritoneal cavity and/or viscera) from $1000 \mathrm{ml} / \mathrm{min}$ to $2500 \mathrm{ml} / \mathrm{min}$, as we found at a flow rate between $700 \mathrm{ml} / \mathrm{min}$ and $900 \mathrm{ml} / \mathrm{min}$, and also, as these authors reported, at rates of $2000 \mathrm{ml} / \mathrm{min}$ and $3000 \mathrm{ml} / \mathrm{min}-$ about $0.8^{\circ} \mathrm{C}$ for both flow rates 2 .

Another point of interest in this context is the dynamic relationship between hyperthermia and intra-abdominal pressures. Hyperthermia enhances diffusion in the visceral peritoneum, whereas increased pressure may enhance both visceral and parietal tissue concentrations of chemotherapy agents, without leading to increased systemic levels. The combination of the two achieves the highest tissue concentrations of chemotherapy, whereas a maximal distention of the abdomen by the perfusate is probably required to improve the synergism between such factors ${ }^{4,5}$.

In conclusion, we present some dynamic relationships between flow rates and temperature parameters that may help in selecting better technical parameters during HIPEC procedures. These data resulted from our pioneering clinical trial in Brazil and also the very first to use the Performer HT device.

\section{ACKNOWLEDGEMENTS}

We would like to thank the medical student Victor A. Siqueira and our perfusionist, Gabriela M. $N$. Henriques, for helping us with data collection; the Rand Company (Medolla, Italy), for the excellent technical assistance; and Dr. Fernando Figueira and Nurse Adriana Pernambuco, for their logistic efforts.

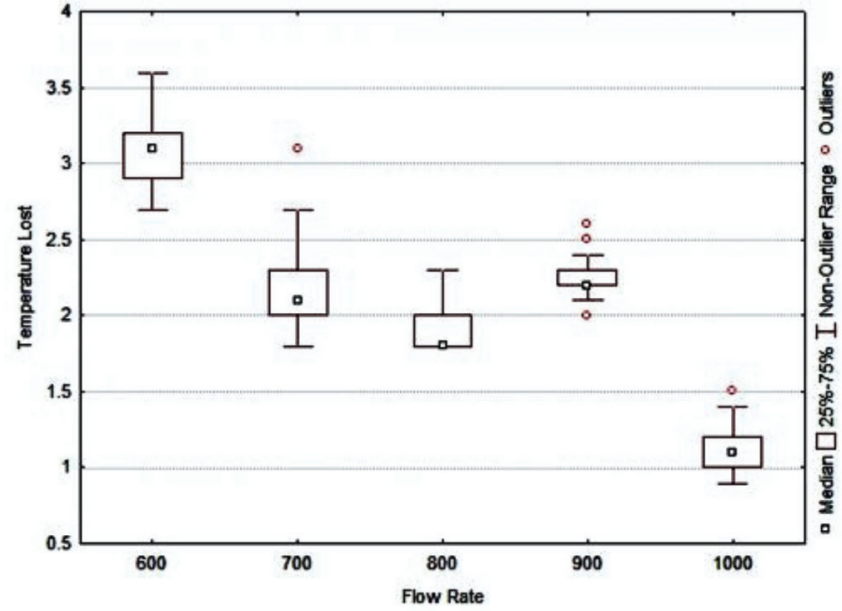

Figure 2. Box Plot of temperature losses to peritoneal cavity (i.e.: differences between inlet and outlet temperature probes) according to flow rates. 


\section{R E S U M O}

Cirurgia citorredutora avançada e quimioterapia intraperitoneal hipertérmica (i.e.: HIPEC, sigla em inglês) têm se consagrado como promissora abordagem terapêutica multidisciplinar para neoplasias malignas peritoneais. Contudo, dados da literatura corrente são muito heterogêneos em torno de muitos de seus aspectos técnicos, o que demanda algum esforço na busca por padronizações do procedimento. Neste sentido, são apresentados dados de um ensaio clínico pioneiro no Brasil (ClinicalTrials.gov Identifier: NCT02249013), relacionando parâmetros dinâmicos de taxas de fluxo e temperaturas de perfusão nos primeiros casos do estudo, o que pode ajudar na seleção de melhores parâmetros técnicos para procedimentos de HIPEC.

Descritores: Injeções Intraperitoneais. Hipertermia Induzida. Quimioterapia. Neoplasias Peritoneais.

\section{REFERENCES}

1. Lambert LA. Looking up: Recent advances in understanding and treating peritoneal carcinomatosis. CA Cancer J Clin. 2015;65(4):284-98.

2. Furman MJ, Picotte RJ, Wante MJ, Rajeshkumar BR, Whalen GF, Lambert LA. Higher flow rates improve heating during hyperthermic intraperitoneal chemoperfusion. J Surg Oncol. 2014;110(8):970-5.

3. Schaaf L, van der Kuip H, Zopf W, Winter S, Münch $M$, Mürdter TE, et al. A temperature of $40^{\circ} \mathrm{C}$ appears to be a critical threshold for potentiating cytotoxic chemotherapy in vitro and in peritoneal carcinomatosis patients undergoing HIPEC. Ann Surg Oncol. 2015;22 Suppl 3:758-65.

4. Rettenmaier MA, Mendivil AA, Gray CM, Chapman $A P$, Stone MK, Tinnerman EJ, et al. Intra-abdominal temperature distribution during consolidation hy- perthermic intraperitoneal chemotherapy with carboplatin in the treatment of advanced stage ovarian carcinoma. Int J Hyperthermia. 2015;31(4):396-402.

5. Facy O, Al Samman S, Magnin G, Ghiringhelli F, Ladoire $S$, Chauffert B, et al. High pressure enhances the effect of hyperthermia in intraperitoneal chemotherapy with oxaliplatin: an experimental study. Ann Surg. 2012;256(6):1084-8.

Received in: 07/08/2016

Accepted for publication: 17/10/2016

Conflict of interest: none.

Source of funding: Decit/SCTIE/MS - CNPq/FACEPE/ SES-PE (APQ:0187-4.01/13) and FAPE/IMIP.

\section{Mailing address:}

Thales Paulo Batista

E-mail: t.paulo@bol.com.br / t.paulo@outlook.com 